\title{
Climate-smart pest management: building resilience of farms and landscapes to changing pest threats
}

\author{
Luca Heeb $^{1}$ (D) Emma Jenner ${ }^{1}$ E $\cdot$ Matthew J. W. Cock ${ }^{2}$
}

Received: 12 June 2018 / Revised: 21 December 2018 / Accepted: 14 January 2019 / Published online: 25 February 2019

(c) The Author(s) 2019

\begin{abstract}
Climate change is affecting the biology, distribution and outbreak potential of pests in a vast range of crops and across all land uses and landscapes. Up to $40 \%$ of the world's food supply is already lost to pests; the reduction in pest impact is more important than ever to ensure global food security, reduced application of inputs and decreased greenhouse gas emissions. Climate-smart pest management (CSPM) is a cross-sectoral approach that aims to reduce pest-induced crop losses, enhance ecosystem services, reduce the greenhouse gas emissions intensity per unit of food produced and strengthen the resilience of agricultural systems in the face of climate change. Through the implementation of CSPM, crop production, extension, research and policy act in coordination towards more efficient and resilient food production systems.
\end{abstract}

Keywords Climate-smart agriculture $\cdot$ Integrated pest management $\cdot$ Crop losses $\cdot$ Adaptation $\cdot$ Mitigation

$\begin{array}{ll}\text { Abbreviations } \\ \text { CAP } & \text { EU's Common Agricultural Policy } \\ \mathrm{COP} & \text { Conference of the Parties } \\ \mathrm{CO}_{2} \mathrm{e} & \mathrm{CO}_{2} \text { equivalents } \\ \mathrm{CSA} & \text { Climate-smart agriculture } \\ \mathrm{CSPM} & \text { Climate-smart pest management } \\ \text { FNC } & \text { Colombian Coffee Grower's Federation } \\ \text { GHG } & \text { Greenhouse gases } \\ \text { ICT } & \text { Information and communication technology } \\ \text { IPM } & \text { Integrated pest management } \\ \text { IRR } & \text { Internal rate of return } \\ \text { NDC } & \text { Nationally determined contributions } \\ \text { NPPO } & \text { National Plant Protection Organisation } \\ \text { RCT } & \text { Randomised controlled trial } \\ \text { SDGs } & \text { Sustainable development goals }\end{array}$

Communicated by N. Desneux.

Luca Heeb

1.heeb@cabi.org

1 CABI, Rue des Grillons 1, 2800 Delémont, Switzerland

2 CABI, Bakeham Lane, Egham, Surrey TW20 9TY, UK

\section{Key message}

- Climate change is affecting the biology, distribution and outbreak potential of pests across all land uses and landscapes.

- Up to $40 \%$ of the world's food supply is already lost to pests-reducing pest impact is crucial to ensure global food security, reduced inputs and decreased greenhouse gas emissions.

- CSPM involves the implementation across farms and landscapes of holistic approaches mostly based on selected existing practical management methods with the aim to achieve the co-benefits of enhanced mitigation of, and strengthened resilience to, climate change.

- CSPM seeks to support multiple stakeholders to act in coordination and at scale to revise and reinforce pest management approaches, as well as develop an appropriate enabling environment to more effectively manage evolving climate change-induced pest threats and invasions.

- Development of effective CSPM will require political leadership to build and resource the necessary linkages. 


\section{Introduction}

Climate change is causing global shifts in temperature, precipitation patterns, as well as an increase in unpredictable, extreme weather patterns. It is already known that climate change has a significant impact on global crop yields (Lobell and Field 2007) and will continue to do so into the future (Beddington et al. 2012; Challinor et al. 2014), but climate change is also directly and indirectly influencing the distribution and severity of crop pests, i.e. 'any species, strain or biotype of plant, animal or pathogenic agent injurious to plants or plant products' (FAO 2013b), across the globe (Juroszek and von Tiedemann 2011; Lamichhane et al. 2015; Macfadyen et al. 2018), which is further affecting crop yields. In many areas of the world, new invasive species are also appearing, facilitated by climate change. Without effective monitoring and management systems in place, these invasive species have the potential to also become important pests in these new areas (Hellmann et al. 2008).

Although some climate change effects can be beneficial, evidence suggests that, overall, pest problems are likely to become more unpredictable and larger in amplitude (Gregory et al. 2009). However, predicting the effects of climate change on pests is not easy due to the complicated interacting influences of increasing atmospheric $\mathrm{CO}_{2}$ concentration, changing climatic regimes and altered frequency/intensity of extreme weather events (Bebber et al. 2013; Gregory et al. 2009). Projections are further challenged by the fact that climate change can also exert its effects on pests indirectly, for example through the differing responses of host crops and natural enemies of pests. For example, differences in the thermal preferences of crop pests and their natural enemies can lead to a loss of synchronisation between the two and an increased risk of host outbreaks (Furlong and Zalucki 2017; Hance et al. 2007). Other indirect pest responses result from changes in the efficacy of pest control strategies (e.g. biological control, synthetic pesticides, etc.) (Barzman et al. 2015; Lamichhane et al. 2015), as well as changes in land use and crop management practices, which can often have a greater effect on pest pressure than the direct effects of climate change alone (Hoffmann et al. 2008; Cock et al. 2013).

If changing climatic factors are examined in isolation, the following impacts on pests are a few examples of the direct and indirect effects that can transpire:

Increases in temperature (even if these are small) can increase the severity of diseases caused by pathogens of crops such as oilseed rape, cereals and potatoes (Barzman et al. 2015). Such increasing pest populations and pressures can lead to more numerous applications of pesticides and fungicides, as illustrated in the USA where increasing temperatures leading to larger insect populations in southern regions have resulted in greater insecticide use compared to cooler, higher latitude regions. A specific example of this is where pesticide sprays for the control of Lepidoptera insect pests in sweet corn (maize) are much higher in Florida (15-32 applications per year) compared with Delaware (4-8 applications per year) and New York (0-5 applications per year) (Hatfield et al. 2011). Such increases in pesticide applications can exert significant negative effects on environmental and human health (Larsen et al. 2017). Increases in temperature can also reduce the effectiveness of certain pesticides, for example, the toxicities of two pyrethroids (lambda-cyhalothrin and bifenthrin) and a spinosyn (spinosad) to Ostrinia nubilalis (Hübner) (Lepidoptera: Crambidae) were found to decrease as post-exposure temperature increased (Musser and Shelton 2005). Even small changes in thermal conditions have also been found to influence the effectiveness of parasitoids in controlling pest species (Thomson et al. 2010) as well as the expression of defensive traits used by insect pests against their larval parasitoids (Iltis et al. 2018). Another study by de Sassi and Tylianakis (2012) in grassland systems in New Zealand demonstrated that although higher temperatures positively affected biomass production, the absolute and relative biomass of herbivores increased disproportionately, and parasitoids did not show any significant response to the changing temperature. The study also concluded that assessing the overall effects of temperature at multiple trophic levels remains difficult; however, a reduction in top-down regulation can coincide with an increase in herbivory, which is likely to have further impacts on other ecosystem processes.

Changing precipitation (excessive or insufficient) can have substantial effects on crop-pest interactions, because many species are favoured by warm and humid conditions, including plant pathogens, which are highly responsive to humidity and rainfall (Hatfield et al. 2011). Also, crops suffering from water stress are more vulnerable to damage by pests (Rosenzweig et al. 2001) as found during floods in Iowa in 1993 that led to an increase in plant diseases such as rust and leaf blight (Munkvold and Yang 1995). Outbreaks of the desert locust are exacerbated by changes in precipitation events, as exemplified by their invasion of more than 10 countries in western and northern Africa in 2004 following heavier than normal rains; this resulted in significant crop losses and food shortages. Locust outbreaks are only likely to become more common with the increase in frequency and severity of precipitation events predicted in the future (Masters and Norgrove 2010).

Increasing $\mathrm{CO}_{2}$ levels can directly lead to enhanced crop yields, but any gains in yield may be offset partly or entirely by losses caused by phytophagous insects, plant 
pathogens and weeds (Coakley et al. 1999). For example, cabbage loopers, Trichoplusia ni (Hübner) (Lepidoptera: Noctuidae) in North America are found to consume a greater volume of leaves under increased $\mathrm{CO}_{2}$ levels, which is thought to be a result of the reduced nitrogen levels found in cabbage leaves growing under these conditions (Trumble and Butler 2009).

Extreme weather events can influence the interactions between crops, pests and diseases in an unpredictable way, potentially resulting in the failure of some crop protection strategies and subsequent reductions in yields (Chakraborty and Newton 2011; Cock et al. 2013; Rosenzweig et al. 2001). For example, one study revealed that extremely dry and hot weather in Slovakia in May 1993 reduced the populations of the egg parasitoid Trichogramma evanescens Westwood (Hymenoptera: Trichogrammatidae) so much so that there was no record of successful parasitism of European corn borer eggs that year (Cagan et al. 1998). Strong air currents in storms can also transport disease agents such as fungal spores or insects from overwintering sites to areas where they can cause further problems (Rosenzweig et al. 2000). Thus, winds associated with Hurricane Wilma spread citrus canker widely in Florida, destroying 170,000 acres of commercially grown fruit trees (Sutherst et al. 2011). Also, ecosystems that have been disturbed due to extreme climatic events are automatically more susceptible and vulnerable to invasions of alien and native species (Masters and Norgrove 2010).

Although climate change-induced pest impacts are variable and subject to numerous interacting factors, changing climatic environments and the resulting changes in land use are anticipated to cause an overall global pattern of increasing latitudinal and altitudinal range of crop pests (Barzman et al. 2015; Gregory et al. 2009). Up to $40 \%$ of the world's food supply is already being lost to pests (Oerke 2006) and as climate continues to change, and further intensifies damage and/or creates new pest threats, it is more important than ever that farmers across the globe start adapting their farm and landscape management practices to protect food production and their livelihoods. Action should not be restricted to the farm level only though. The impact of enhanced pest pressure and crop losses extends beyond the farm, to local, national and international food security, as well as environmental, economic and social sustainability. Immediate action is therefore needed on multiple levels and geographical scales, particularly as pest-related yield losses due to climate change have so far gained little attention compared to human or animal health affected by climate change.

While science has directly addressed the issue of pest management in a changing climate, and the need to revisit existing preventive agricultural practices and integrated pest management (IPM) strategies in order to develop locally adapted and diversified agroecosystems resilient enough to tolerate extreme weather fluctuations (Barzman et al. 2015; Chakraborty and Newton 2011; Juroszek and von Tiedemann 2011; Lamichhane et al. 2015; Macfadyen et al. 2018; Strand 2000), information is often specific to a particular type of pest or geographic region. What is lacking is a clear approach that brings all of the documented IPM recommendations and tools together under one umbrella with a strong focus on adapting to climate-induced change and recognising the potential of pest management for climate change mitigation. This approach will require public support and political leadership and needs to be embedded within a favourable enabling environment because without the effective coordination of multiple stakeholders, the large-scale development and uptake of new and adaptive pest management approaches will be unsuccessful at worst and inefficient at best.

'Climate-smart agriculture' (CSA), as promoted by FAO (2010), is a well-documented approach aiming to help guide actions needed to reorient entire agricultural systems in order to support development and ensure food security in a changing climate. Within this approach, however, the topic of pest management receives relatively little attention beyond recommending IPM as a sound strategy, most likely due to the same problem outlined above, that information in the literature is scattered and context-specific. In response to this, the new approach of climate-smart pest management (CSPM, Fig. 1) has been developed, as outlined in this review, to address this need and provide more detailed and focussed pest management guidance within the broader approach of CSA. Accompanied by the CSPM toolbox (Table 1), it provides recommendations across multiple stakeholder levels and geographical scales to guide producers, extension agents, researchers, policymakers and the wider public and private sector in the development of proactive and reactive strategies against climate-induced global changes in crop pests. It also explains how CSPM supports the achievement of national, regional and global climate change adaptation and mitigation goals, and in doing so supports global food security and farmer livelihoods through enhancing the sustainability of agricultural systems, their dependent livelihoods and surrounding environments. At the 23rd Conference of the Parties (COP23) meeting in 2017, under the United Nations Framework Convention on Climate Change, all 197 parties reaffirmed their commitment to contribute to global emissions reductions and adaptation to the impacts of climate change through their Nationally Determined Contributions (NDCs) (CCAFS 2017). Many parties have specifically highlighted agriculture, land use and pest management as focal areas for adaptation and emissions efforts in their NDCs, and thus, the emergence 


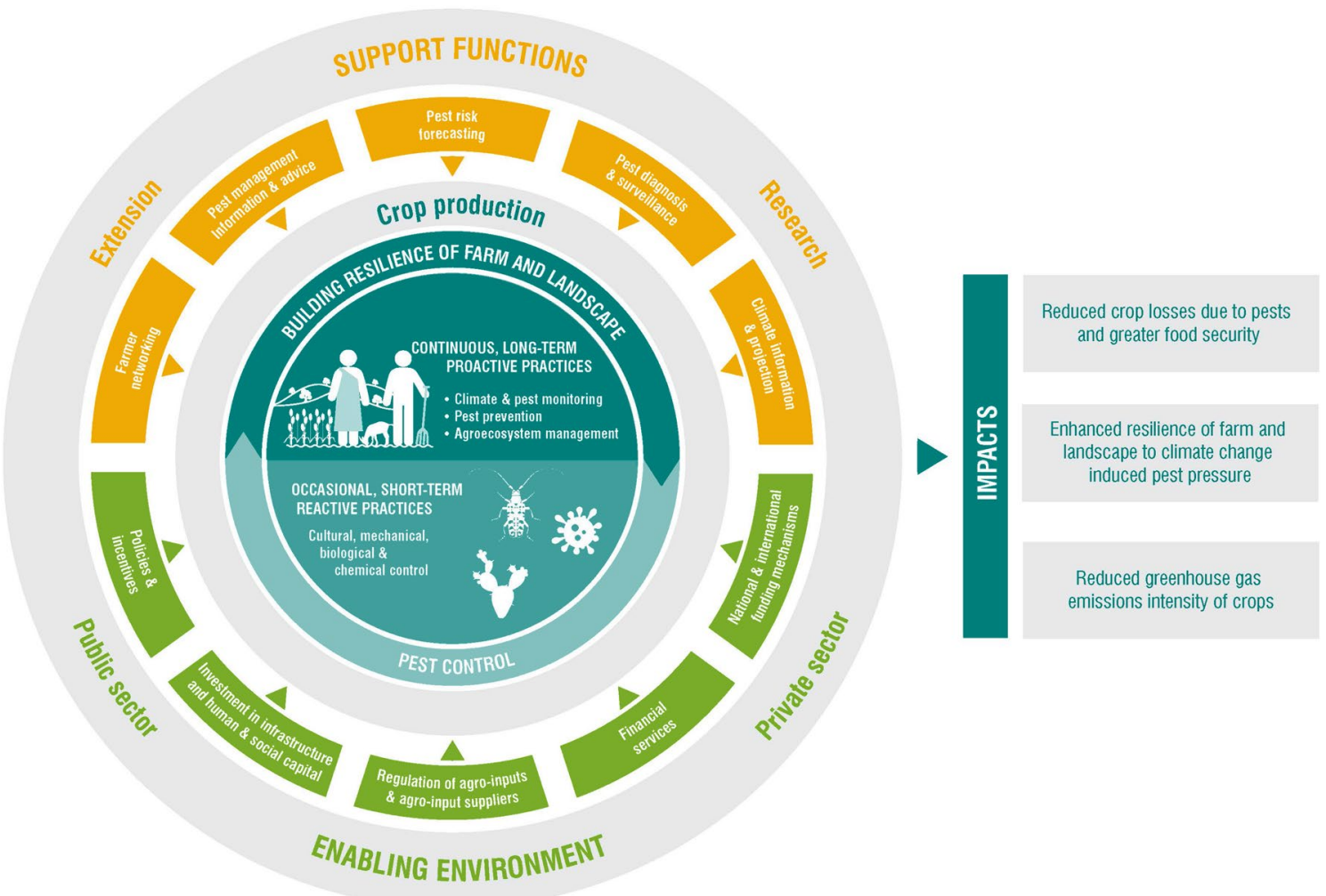

Fig. 1 Climate-smart pest management (CSPM) is an interdisciplinary approach aiming to increase resilience of farms and landscapes to changing pest threats, mitigate greenhouse gas emissions and contribute to food security

of the concept of CSPM is very timely as it can be used to inform the transformation of these intended contributions into concrete national action plans.

\section{Overview of climate-smart pest management}

The concept of CSPM is new and encompasses a set of interdisciplinary approaches and strategies needed for primary production to adapt, with its supporting functions (e.g. extension and research) and enabling environment (e.g. policies, infrastructure and social/human capital), to the changing climatic environment, which, together with land use characteristics, sets and influences the boundaries for geographical distributions of species (crops, pests and natural enemies). Implementing the CSPM concept enables more effective management of the increased threat posed by new and existing crop pests to agricultural production and ecosystem services, and therefore increases resilience of farmer livelihoods and overall local and national food security to climate change. CSPM also contributes to mitigation of climate change through improving overall greenhouse gas (GHG) balance; a reduction in pest-related yield losses, for example, decreases the GHG emissions intensity per unit of food produced.

To be effective, CSPM should not be understood as a stand-alone approach, but as a part of a broader CSA intervention, which considers pest management as one of its key components. As Fig. 1 shows, CSPM will provide farmers with the information and tools in hand to immediately and proactively put into action pest prevention practices (e.g. crop diversification, establishment of natural habitats and careful water management) that will enhance the health of their farms and the surrounding landscape, and reduce susceptibility to pest-induced disturbance. Moreover, through climate and pest monitoring, in combination with climate and pest risk forecasting information [e.g. as carried out by the Agrhymet Regional Centre (Agrhymet 2013)], farmers will be able to proactively identify and implement specific pest prevention practices in order to prevent the occurrence and/or buildup of expected pest problems. In cases where pest populations do reach economic injury levels, CSPM enables 
Table 1 Climate-smart pest management toolbox: examples of underlying approaches

\begin{tabular}{|c|c|c|}
\hline CSPM focal points & Climate-smart pest management toolbox: examples of underlying approaches & Contribution \\
\hline \multicolumn{3}{|l|}{ Production } \\
\hline $\begin{array}{l}\text { Building resilience of farm } \\
\text { and landscape }\end{array}$ & $\begin{array}{l}\text { - Conduct climate and pest monitoring to be able to predict and respond rapidly to new, emerging and existing pests } \\
\text { - Implement pest prevention approaches to discourage the establishment and development of pest populations } \\
\text { - Apply agroecosystem management to support ecosystem services and enhance the resilience of farms and land- } \\
\text { scapes to changes in climate and pest pressures }\end{array}$ & $\begin{array}{l}\text { Productivity } \\
\text { Adaptation } \\
\text { Mitigation }\end{array}$ \\
\hline Pest control & $\begin{array}{l}\text { - Implement mechanical, cultural, biological and chemical (last option) approaches to reduce pest damage and } \\
\text { pest-induced crop losses }\end{array}$ & $\begin{array}{l}\text { Productivity } \\
\text { Mitigation }\end{array}$ \\
\hline \multicolumn{3}{|c|}{ Extension and research (SUPPORT FUNCTIONS) } \\
\hline Farmer networking & $\begin{array}{l}\text { - Improve farmer networks and organisations and promote links to technology providers to enhance knowledge } \\
\text { sharing and improve access to information about climate-smart pest management technologies and practices, } \\
\text { thereby facilitating their uptake }\end{array}$ & $\begin{array}{l}\text { Productivity } \\
\text { Adaptation }\end{array}$ \\
\hline $\begin{array}{l}\text { Pest management informa- } \\
\text { tion and advice }\end{array}$ & $\begin{array}{l}\text { - Conduct participatory appraisals of current extension systems to identify structural weaknesses, understand link- } \\
\text { ages to other stakeholders and allow challenges to be prioritised and addressed in order to provide farmers with a } \\
\text { high-quality extension support system } \\
\text { - Enhance accessibility of extension services for farmers and ensure consistent and frequent engagement through } \\
\text { methods that allow a two-way flow of information (i.e. transfer of pest-related information to farmers and subse- } \\
\text { quent collection of farmers' feedback for validating and adaptation of pest control strategies) } \\
\text { - Establish vibrant two-way linkages between extension institutions and expertise (e.g. research, diagnostic facili- } \\
\text { ties) } \\
\text { - Develop new climate-smart pest management (CSPM) technologies and approaches based on current needs and } \\
\text { local contexts } \\
\text { - Establish interdisciplinary knowledge creation (with local validation), knowledge exchange and knowledge } \\
\text { management systems for CSPM information to ensure sound recommendations for farmers and allow information } \\
\text { sharing within and between national and international stakeholders } \\
\text { - Implement studies and develop methodologies to assess GHG emissions reduction potential for pest management } \\
\text { approaches }\end{array}$ & $\begin{array}{l}\text { Productivity } \\
\text { Adaptation } \\
\text { Mitigation }\end{array}$ \\
\hline Pest risk forecasting & $\begin{array}{l}\text { - Conduct basic research to determine likely impacts of climate change on pest establishment, development, phe- } \\
\text { nology, behaviour, interactions with host and natural enemies, etc. in specific agricultural settings } \\
\text { - Develop models of pest outbreak potential and impact to enable informed and climate-responsive pest manage- } \\
\text { ment decision-making } \\
\text { - Develop/implement early warning systems to support prevention and rapid response to new and existing pests, as } \\
\text { well as limit in-country and cross-border spread }\end{array}$ & $\begin{array}{l}\text { Productivity } \\
\text { Adaptation }\end{array}$ \\
\hline $\begin{array}{l}\text { Pest diagnosis and surveil- } \\
\text { lance }\end{array}$ & $\begin{array}{l}\text { - Develop tools for, and improve, monitoring of existing pests as well as surveillance for and identification of new } \\
\text { pests to enable rapid and targeted short-term responses and long-term adaptation planning } \\
\text { - Implement effective data collection systems for pest surveillance, linked to national/international diagnostic sup- } \\
\text { port services, to enable fast detection of new and emerging pests, assess current pest management practices used } \\
\text { by farmers and inform development of short- and long-term management approaches }\end{array}$ & $\begin{array}{l}\text { Productivity } \\
\text { Adaptation }\end{array}$ \\
\hline $\begin{array}{l}\text { Climate information and } \\
\text { projection }\end{array}$ & $\begin{array}{l}\text { - Enhance availability and accuracy of climate information (down-scaled historical, monitored and predicted) to } \\
\text { enable farmers to make informed decisions, better manage risk, take advantage of favourable climate conditions } \\
\text { and adapt to change }\end{array}$ & Adaptation \\
\hline \multicolumn{3}{|c|}{ Public and private sector (ENABLING ENVIRONMENT) } \\
\hline Policies and incentives & $\begin{array}{l}\text { - Develop public policies and regulatory instruments such as incentive-based systems that recognise CSPM imple- } \\
\text { mentation (e.g. food labels, taxes, subsidies) to incentivise and reward/penalise farmers who adopt/do not adopt } \\
\text { CSPM practices }\end{array}$ & $\begin{array}{l}\text { Adaptation } \\
\text { Mitigation }\end{array}$ \\
\hline $\begin{array}{l}\text { Investment in infrastructure, } \\
\text { and human and social } \\
\text { capital }\end{array}$ & $\begin{array}{l}\text { - Identify knowledge gaps and implement training for decision makers to promote awareness, inclusiveness, owner- } \\
\text { ship, sustainability and effective development and uptake of CSPM policies } \\
\text { - Invest in training programmes and infrastructure (e.g. ICTs) to enhance efficiency and impact of national exten- } \\
\text { sion systems and research institutions } \\
\text { - Build structures that enhance connectivity of farmers (e.g. knowledge centres, to enable smallholders to access } \\
\text { information, technologies and resources necessary to adapt to climate change and potentially access new markets }\end{array}$ & $\begin{array}{l}\text { Productivity } \\
\text { Adaptation } \\
\text { Mitigation }\end{array}$ \\
\hline $\begin{array}{l}\text { Regulation of agro-inputs } \\
\text { and agro-input suppliers }\end{array}$ & $\begin{array}{l}\text { - Monitor/regulate agro-input suppliers and build climate literacy to increase outreach of reliable CSPM knowl- } \\
\text { edge (especially in developing countries, where agro-input suppliers are primary source of information for many } \\
\text { farmers) } \\
\text { - Implement effective regulatory procedure to register and control available agro-inputs and monitor the quality of } \\
\text { those products once on the market }\end{array}$ & $\begin{array}{l}\text { Productivity } \\
\text { Adaptation } \\
\text { Mitigation }\end{array}$ \\
\hline Financial services & $\begin{array}{l}\text { - Establish, and enhance access to, financial mechanisms, including climate insurance, crop insurance, access to } \\
\text { micro-credit, etc. to increase farmers' capacity to invest in farm- and/or landscape-level changes in their produc- } \\
\text { tion systems }\end{array}$ & $\begin{array}{l}\text { Productivity } \\
\text { Adaptation } \\
\text { Mitigation }\end{array}$ \\
\hline $\begin{array}{l}\text { National and international } \\
\text { funding mechanisms }\end{array}$ & $\begin{array}{l}\text { - Establish national special funds for developing and implementing local adaptation plans that include CSPM } \\
\text { - Apply for international funds (e.g. Green Climate Fund and bilateral donors) for implementation of projects/ } \\
\text { programmes to achieve Nationally Determined Contributions (NDC) targets and piloting of CSPM approaches as } \\
\text { proof of concept and to catalyse adoption by farmers }\end{array}$ & $\begin{array}{l}\text { Productivity } \\
\text { Adaptation } \\
\text { Mitigation }\end{array}$ \\
\hline
\end{tabular}


farmers to make rapid, informed decisions regarding the most appropriate reactive pest control strategy.

Although pest management approaches are implemented by farmers, CSPM must be addressed more broadly than just at the farm-level, which requires science-based political leadership. The immediate impact of enhanced pest pressure and crop losses is on farmer income and livelihoods (particularly in the case of smallholder farmers), but the knock-on effects of misuse of chemical pesticides and reduced yields are much broader and can lead to severe problems in the broader ecosystem and its ability to support vital ecosystem services. It can also adversely affect local and national food security, economy and employment, as well as lead to a number of socio-economic consequences, including domestic and international migration. CSPM is not the sole responsibility of farmers, as it fosters coordinated support from extension and research and suggests approaches and practices to ensure that the services they provide are relevant, locally adapted and accessible to all farmers, including those that are often marginalised (e.g. women, elderly and ethnic minorities). For example, universities and national agricultural research centres conducting on-the-ground research to determine the likely impacts of climate change on crop-pest-natural enemy dynamics, and quantifying the consequences of these impacts, will facilitate the development of targeted adaptive responses that are currently lacking. In addition, the analysis of historical weather and climate data, as well as the development of niche models to determine pest species' potential distribution under varying climatic scenarios, will allow pest risk forecasting to become a viable tool to guide proactive pest prevention/management strategies (Yonow et al. 2018). CSPM also places a significant emphasis on creating the necessary enabling environment to catalyse adoption of CSPM approaches. For example, public and private sector investment is crucial for enabling supporting institutions to carry out their mandate (especially in developing countries), as well as for enhancing the infrastructure required for effective exchange of information and knowledge between stakeholders. The development of appropriate policies (e.g. incentive-based systems) that reward CSPM implementation is encouraged, together with the establishment of financial services that enable farmers to overcome adoption costs and increase their risk-appetite for trying new agricultural practices. A good example of this is in China, where the 'China Green Control Policy' provides a subsidy framework for 'non-chemical and least toxic plant protection measures' and enforces it in partnership with a development programme, Plantwise, led by CABI.

\section{Benefits of Climate-Smart Pest Management (CSPM)}

Food Security CSPM leads to effective and cost-efficient management of existing crop pests, thereby reducing crop losses to pests and increasing both food security and income for male and female farmers.

Adaptation CSPM decreases negative impacts on the broader ecosystem, making farming systems more resilient to climate change. At national and global levels, CSPM revitalises the important role of extension, research and the public and private sectors for pest forecasting, surveillance, detection and control, as these are vital services to increase resilience.

Mitigation CSPM contributes to increasing the efficiency of agricultural production (through a reduction in avoidable yield losses) and promotes a rational use of agricultural inputs, thereby reducing the GHG emissions intensity per unit of food produced.

Double/triple wins CSPM considers adaptation and mitigation strategies simultaneously wherever possible. For example, proactive pest prevention practices, such as mulching, minimum tillage and planting natural barriers, not only increase organic carbon sequestration in soil and biomass, but also increase resilience to certain pests. This is important because if adaptation strategies are devised in isolation from mitigation strategies then there is an increased risk of intensifying emissions, for example, through enhanced use of agrochemicals to promote productivity. Together with the reduction in pest-induced crop losses that these practices bring, a triple-win effect of adapting to evolving pest threats, mitigating GHG emissions and ultimately improving food security can be achieved.

Delivery of Sustainable Development Goals (SDGs) CSPM directly contributes to a number of SDGs: SDG $1-$ No Poverty and SDG 2-Zero Hunger (through its direct impact on crop production and income); SDG 12-Responsible Consumption and Production (through reduction in food losses at the primary production stage); SDG 13-Climate Action (through, among others, reducing GHG emission intensity per unit of food produced); and SDG 15-Life on Land (through conserving biodiversity and maintaining ecosystem services).

\section{Implementation of climate-smart pest management}

It is worth noting that CSPM as a fully fledged approach as described in Fig. 1 has not (yet) been adopted as a formal framework by any country to the authors' knowledge. This is because the approach as it is presented here is a novel idea. However, there are many countries that have taken up specific components of CSPM, as the examples in this paper demonstrate. In the longer term, the authors anticipate that CSPM will be absorbed into national agricultural policies, mandatory and/or voluntary standards and production approaches such as IPM or agroecological farming. Institutionalisation of CSPM, either partially or entirely, will be key to ensuring its uptake and sustainability. This will be facilitated by the fact that many practices under the CSPM umbrella are not new and in terms of production, the approach includes many of the carefully researched and locally adapted, field-, farmand landscape-based sustainable pest management or IPMpractices that are already well-documented in the literature and being practiced by farmers across the world. Hence, there will be scope for sharing experiences between regions and 
between countries as climate changes. The implementation of CSPM therefore does not necessarily pose a significant amount of additional work or investment for farmers. The key issue is ensuring that these practices are improved in the context of a changing climate, which necessitates the integration of local climate observation and forecasting, as well as pest risk assessment, into the pest management planning process. For example, knowing the effect of spring weather patterns on the populations of Helicoverpa armigera (Hübner) (Lepidoptera: Noctuidae) and other insect species means that spring weather observations can be used to improve forecasting of insect pest abundance and better inform pest management (Gu et al. 2018). Also crucial for the successful implementation of CSPM is a suitable enabling environment to ensure optimal resilience of farmers in their local environment so that they are able to cope with existing impacts as well as be prepared for future impacts.

\section{Roles and responsibilities}

One of the main challenges to implementing CSPM is that it is not possible to generalise and make CSPM recommendations across large and diverse geographical areas. Equally, across the breadth of low- to high-income countries, it is difficult to generalise as to who should take which roles, and how they will be resourced, so we give some varied examples. Early warning of annual invasive or outbreak pests is an important activity to support farmers in some areas and this is often carried out by different stakeholders, e.g. locust and armyworm predictions in Africa are made by international groups and aphid invasion monitoring and prediction in Europe is carried out by national agricultural research groups. The annual northward spread of major migratory pests in China (Cock et al. 2016) is monitored and forecast by the National Agricultural Technology Extension and Service Center (NATESC), a non-profit institution under the Ministry of Agriculture. Their forecasts and advice pass through five levels of public extension agencies: national, provincial, prefectural, county and township levels. At the township level, the extension service provides a comprehensive agricultural service centre. New information generated from remote sensing, and other monitoring and forecasting approaches would be cascaded to county-level and/or township-level extension stations/plant protection stations who will pass the information to village heads and then farmers via different channels (such as trainings, meetings, phone calls, SMS, leaflets, village broadcast systems, local TV and mass media) with minimum delay. With these channels, approximately $90 \%$ of farmers can be informed which pest needs to be controlled with which approaches, although dissemination could be slower than ideal. Experiences from the more than 30 countries involved in the Plantwise approach to plant health system development show that National
Plant Protection Organisations (NPPOs; see www.ippc.int/ en/countries/nppos/list-countries/) are key stakeholders for obtaining high-level buy-in and ensuring country-wide coordination. However, strong ownership by, and collaboration with, other governmental and non-governmental institutions, such as extension or research divisions, are equally important as plant health system development goes far beyond the mandate of the NPPO. This will also be the case for CSPM, the success of which therefore very much depends on public support, political leadership, stakeholder coordination, and the sharing of roles and responsibilities. It must also be remembered that many developing countries have undergone or are currently undergoing a process of devolution to the provincial level (e.g. Pakistan, Kenya, Nepal). This delegation of powers needs to be considered when implementing CSPM because through this process various sub-national authorities may become potential sources of funding and will need to be convinced that investments into approaches such as CSPM will yield a positive return.

\section{Assessment, selection and evaluation of CSPM options}

As with all sustainable agricultural approaches, including IPM and CSA, CSPM is highly context-specific (Beuchelt and Badstue 2013; FAO 2013a; Neufeldt et al. 2013; Scherr et al. 2012) and recommended approaches will depend on the climatic, agricultural, ecological, social, economic and political environment, at household, farm, community and national levels. Just as CSA requires site-specific assessments to identify suitable agricultural production technologies and practices (FAO 2013a), the first step of any CSPM programme is to conduct a thorough appraisal of the local environment and perspectives. This serves as a basis for the second step, which is to identify the most locally appropriate CSPM approaches, taking into consideration the various contexts, including socially differentiated groups (i.e. gender, age, etc.) (Mwongera et al. 2017). Since there is no 'one size fits all' strategy for CSPM, the toolbox (Table 1) illustrates a diversity of CSPM options. The toolbox is interdisciplinary and can be used for the selection, elaboration and implementation of locally adapted CSPM technologies, practices, research agendas, extension material, policies and other activities. It also supports the creation of the required enabling environment to facilitate effective and rapid adoption of CSPM across farms, landscapes, countries and regions. Following the selection of CSPM tools, it is important that they are evaluated in the local context before they are implemented, to assess how well and cost-effectively they will achieve the goals they set out to address. Implications for other farm management decisions should be considered, for example, changing to a pest-tolerant crop variety may require only minimal investment and knowledge, whereas changing 
crops because of a new pest invasion may involve investing in new seeding and harvesting equipment, implementing new crop rotation practices and sourcing new buyers and markets for the produce (Macfadyen et al. 2018). This overall process of assessment, selection and evaluation of CSPM options is normally a role for the national agricultural research system (primarily national and industry research centres and agriculturally focussed universities), either as a stand-alone activity or part of a regional programme, and sometimes in collaboration with international agricultural research centres. Funding may be from national research bodies, ministries or industry groups, especially in medium- to high-income countries, or with international donor support in low-income countries (which will also help build national capacity).

\section{Interlinking activities and stakeholders}

Since CSPM activities involve multiple stakeholders and institutions, and take place at a range of scales (Chakraborty and Newton 2011), interlinking CSPM activities and stakeholders is crucial to overcome barriers that hinder its implementation. However, who the key stakeholders are and how they link to each other will vary with the pest management activity and the national infrastructure, which in turn is dependent on national investment of resources. Enhanced linkages between extension, research and the public/private sector, for example, can help to provide the data and resources required to improve diagnosis of new and emerging pests, inform policies and research agendas, and reduce response time to these pest threats. Particularly in developing countries, extension services need strong linkages to diagnostic support, to help ensure field diagnoses of pests are as accurate as needed to make appropriate recommendations (Cock 2011; Mugambi et al. 2016). This will be increasingly essential as the relative importance of crops and pests change in response to climate change and pests spread into new areas where neither extension staff nor farmers are familiar with them. Such diagnostic support may be very limited in-country; it is difficult to be specific but where present, the key expertise will normally be found in the national agriculture service, universities and/or museums. Linkages with extension services may be weak or non-existent, and financial support for simple things such as the movement of samples within country for diagnosis and identification may be missing. Linkages between extension staff and national diagnostic and taxonomic expertise merit strengthening, which will require national organisation and resources. Incountry expertise will not cover all pest groups and linkages to international expertise in specialist taxonomic areas will be needed, and the international movement of biological samples for identification needs to be facilitated under national phytosanitary and genetic resources regulations. Particularly where resources and facilitation are limited, extension staff will turn to alternative options, such as online pest diagnostic support (e.g. PlantVillage or PestPoint; www.plantvilla ge.psu.edu, www.pestpoint.org.au), especially where images can be shared, or image recognitions tools (e.g. Plantix; www. plantix.net). Extension staff will also form their own social media groups to exchange images and seek the advice of their peers (e.g. Mugambi et al. 2016). Every extension service will develop diagnostic support as best suits the national circumstances. One step further would be the development of a knowledge platform that collects data, key information, tools, etc. from existing sources, makes this freely available and facilitates knowledge sharing and development of innovative solutions on a regional and/or global level (e.g. the Plantwise Knowledge Bank; www.plantwise.org/KB).

\section{Monitoring and evaluation}

Finally, CSPM is a dynamic and evolving approach and so continual monitoring and evaluation is required to assess the implementation and short-term outcomes and impacts of CSPM interventions, and to allow continual re-evaluation of tools and approaches.

\section{Contribution to climate-smart agriculture}

CSPM is designed to become a key component of CSA and will therefore contribute to the three main objectives that CSA aims to tackle: adapting and building resilience to climate change; reducing and/or removing greenhouse gas emissions; and sustainably increasing agricultural productivity and incomes. The following section outlines a few examples of how CSPM has the potential to support these goals.

\section{Adaptation and increased resilience to climate change}

\section{Short-term and long-term adaptive measures}

Adapting to climate change can be viewed as an ongoing process of implementing existing risk management strategies and reducing the potential risk posed by the consequences of climate change (Howden et al. 2007). With regards to pest management, CSPM recognises that adaptive measures to climate change can be short-term or long-term (Juroszek and von Tiedemann 2011; Olesen and Bindi 2002). Shortterm adjustments include efforts to optimise production without major system changes, e.g. moving to adapted crop varieties that are more resilient to climate change-related stresses, or application of biological or synthetic pesticides to control certain pests. Long-term adaptations include major structural changes to overcome adversity caused by climate change (e.g. introducing crop rotation/intercropping 
to control pests, or changing to a novel crop) (Olesen and Bindi 2002). Regardless of whether measures are short- or long-term, CSPM acknowledges that input from multiple stakeholders will often be required for their identification, development and implementation.

\section{Prediction and recognition of future pest outbreaks}

An increasing number of (new) pests are being seen, especially in the northern hemisphere due to poleward movement, and at higher altitudes due to upslope movement. For example, the southern green stink bug (Nezara viridula (Linnaeus), Hemiptera: Pentatomidae) has expanded its range northward in temperate regions of Europe and Japan since the 1960s, most likely because of reduced mortality due to milder winter temperatures (Musolin 2007). Nandudu (2014) states that coffee leaf rust disease caused by the black coffee twig borer (Xylosandrus compactus (Eichhoff), Coleoptera: Curculionidae), which has normally only affected coffee plants at altitudes below $1400 \mathrm{~m}$ above sea level, has now reached $1800 \mathrm{~m}$ above sea level. This movement in altitude of black coffee twig borers has led to crop damage in far more elevated locations than the industry is accustomed to. Nandudu notes that $85 \%$ of the coffee farms in Uganda are family operated and are facing alarmingly low yields. CSPM highlights the importance of developing more effective diagnostic processes for the identification of pests and their natural enemies in order to be able to make pest management decisions going forward (Cock et al. 2017; Lamichhane et al. 2016; SciDevNet 2013). CSPM also recognises that quantitative modelling (including climate models, empirical models, population models and simulation models) is needed to investigate multiple interactions simultaneously (Coakley et al. 1999) and most importantly, model results need to be interpreted alongside social and ecological model outputs, in order to support countries in developing the most appropriate responses to future pest outbreaks.

\section{Suppression of pest outbreaks and pathogen transmission}

Pests are expected to respond to changing climate conditions more rapidly than plants, so for a pest management system to be resilient it must be ready to withstand both pests that are moving into the area and outbreaks of existing populations. Therefore, CSPM encompasses (i) pest prevention, i.e. development and implementation of biosecurity action plans, raising awareness of threats at the local level and preventing arrival and spread; (ii) early detection and rapid response, i.e. development and implementation of surveillance and emergency action plans for detecting and eradicating listed species, and building capacity to implement these plans; and (iii) management, i.e. evaluating and scaling up existing management solutions, and developing and scaling up new solutions to ensure those living in rural communities have in place the best practice and locally adapted solutions.

\section{Enhancement of health and pest resilience of farms and landscapes}

It has been found that farms with higher levels of biodiversity show a greater resilience to climate disasters such as hurricanes and droughts (Altieri 2012; Altieri et al. 2015). For that reason, CSPM promotes crop diversification, a method of enhancing farm biodiversity, that also promotes the abundance of natural enemies (Lin 2011), and this can be achieved by diversifying production (e.g. from mono-cropping to strip-cropping) to provide refuges for natural enemies that will contribute to pest suppression. Alternatively, annual and perennial non-crop vegetation can be introduced, increasing crop diversity either in situ or ex situ (Lin 2011). Crop diversification can also reduce the risks of pests becoming more severe as a result of climate change (Juroszek and von Tiedemann 2011). Herbivore suppression, natural enemy enhancement and crop damage suppression effects were significantly stronger on diversified farming systems than on fields with no or fewer associated plant species (Altieri 2012). CSPM promotes many other methods that can be employed to increase a system's resilience to climate change, such as crop variety selection, planting dates, conservation tillage methods and mulching (Table 1).

\section{Strengthening of a climate-responsive extension system}

Because of the difficulty of predicting biological responses of pests to climate change in terms of their distribution and population dynamics, it remains unlikely that in the short term any general models can be developed to predict climate change-induced pest outbreaks on a local scale (Lamichhane et al. 2015; Scherm 2004). Inevitably, this increases the vulnerability of farmers, who routinely have to make vital decisions in response to unpredictable conditions and unknown risks, and this can only worsen with the impacts of climate change. If farmers do not have access to the right information at the right time, this poses a great threat to crop production, agroecosystem functioning and livelihoods. One approach that is promoted by CSPM to increase resilience to such unpredictable events is the development of a more responsive national extension system and the promotion of functioning links between extension, research and farmers (Susko et al. 2013). This revitalisation of the rural advisory system plays a pivotal role and should lead to extension being able to fulfil the twofold role of:

- Contributing to the early detection of changing pest threats, which requires that extension workers are skilled and linked to appropriate information and communications technologies (ICT)-based reporting and diagnostic systems and services (Heeb et al. 2016); 
- Repackaging and delivering farmer-friendly science-based pest management information directly into the hands of farmers, e.g. using ICT-based communication channels, such as mobile phones, radio or television, which are costeffective and versatile solutions (Heeb et al. 2016).

To enable extension systems to fulfil these roles, CSPM recognises that there must be quantitative investment (e.g. increasing the ratio of extension workers to farmers and promoting digital development) and qualitative investment (i.e. revisiting extension training programmes and investing in building climate literacy), see 'costs, benefits and funding for climate-smart pest management' section for some examples. It is also important to consider and include private sector extension mechanisms when assessing investment requirements of national advisory systems since they already play an important role for semi-commercial and commercial-oriented smallholders. Repurposing extension services so that landscape considerations prevail over plot-based advice is also crucial.

Increased resilience through ICT-enabled extension - the Plantwise example

A successful example of building the necessary institutional capacity of the extension service, and developing the required technology support system to contribute to early detection and provision of management advice for new pests, is the Plantwise approach, adopted by over 30 countries around the globe. Under this approach, national extension providers equip extension officers with handheld tablet devices, which are used to access pest-management information and can submit real-time GPS-tracked pest observation records directly from the field. Figure 2 demonstrates how the presence of a viral disease of maize was documented by extension agents long before it was officially reported by the national authority responsible for pest reporting, demonstrating the transformative power of information and communications technology (ICT) for information delivery, pest surveillance and resilience.

\section{Reduction in greenhouse gases}

A significant amount of GHG emissions contributing to global climate change originate (directly or indirectly) from agricultural production, including those related to pest control (Beddington et al. 2012). In addition, inappropriate pest management leads to avoidable crop losses and increases emissions intensity per unit of food produced. There is therefore considerable potential for modification of agricultural systems in order to reduce these anthropogenic emissions (Rosenstock et al. 2016). Opportunities for reducing GHG emissions in CSPM fall into three broad categories - as is the case for agriculture as a whole. These categories are (1) reducing emissions, (2) enhancing removals (including carbon sequestration) and (3) avoiding emissions (Smith et al. 2008, 2014).

\section{Reducing emissions}

When CSPM is implemented efficiently and decreases avoidable yield losses, it directly contributes to a reduction in emissions per unit of food produced (i.e. emissions intensity). For example, controlling foliar disease in winter wheat in the UK, through the use of resistant cultivars and fungicides, has been shown to reduce the GHG emissions associated with each tonne of grain produced (Berry et al. 2008). Fungicide treatments on barley reduced GHG emissions by $11-16 \%$ for winter-grown barley and by $8-11 \%$ for spring barley (Hughes et al. 2011). However, the application of agrochemicals to reduce GHG emissions presents a long-term trade-off between adaptation and mitigation goals because it is known that reduction or avoidance of pesticides increases farming system resilience to unexpected pests through positive effects on biodiversity. In

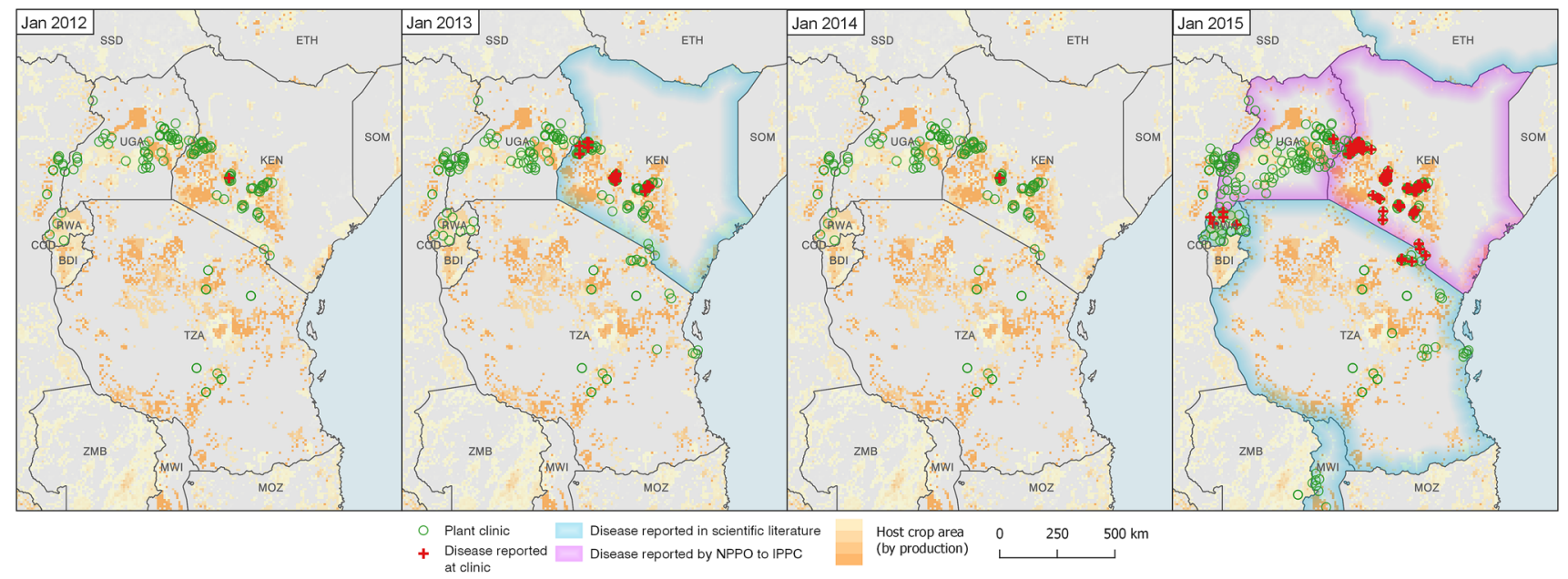

Fig. 2 Spread of a plant disease in East Africa, 2012-2015, as recorded by data collected by extension workers, official National Plant Protection Organization (NPPO) reports recorded on the IPPC's International Phytosanitary Portal, and the scientific literature (Jenner et al. 2019) 
addition, pesticides can indirectly generate additional external costs, for example, related to human health and water quality.

\section{Enhancing removals}

Efficient pest management can contribute to the removal of $\mathrm{CO}_{2}$ from the atmosphere. For example, pest management approaches that lead to significantly higher crop yields also result in additional $\mathrm{CO}_{2}$ assimilation by crop plants (Kern et al. 2012). Furthermore, the long-term CSPM goal of maximising plant diversity and soil organic matter (e.g. through conservation agriculture) not only contributes to carbon sequestration, but can also enhance plant resistance and tolerance against insect pests (Altieri and Nicholls 2003). In addition, CSPM recognises that pest management can potentially reduce indirect emissions as shown in an example of barley in the UK, where it was estimated that without fungicide application, $16 \%$ more land would be needed to produce the same amount of crop, with the associated release of carbon into the atmosphere because of land use change (Hughes et al. 2011).

\section{Avoiding emissions}

CSPM can also lead to total avoidance of GHG emissions due to pest management, based on the different approaches it uses compared with conventional pest management employed in many high-input farming systems. It is estimated that the manufacture, transport and application of insecticides against the soybean aphid has led to annual emissions of between 6 and 40 million $\mathrm{kg} \mathrm{CO}_{2}$ equivalents $\left(\mathrm{CO}_{2} \mathrm{e}\right)$ in the USA since the invasion of that pest. Adopting an economic threshold to limit pesticide application can lead to emission reductions of approximately 300 million $\mathrm{kg}$ of $\mathrm{CO}_{2} \mathrm{e}$ per year (Heimpel et al. 2013). The same authors also noted that natural enemies such as ladybird beetles (Coccinellidae) are capable of suppressing aphid densities below this threshold in over half of the soybean acreage in the USA, which results in the avoidance of over 200 million $\mathrm{kg}$ of $\mathrm{CO}_{2}$ annual emissions. These examples show that although pesticide manufacturing alone only represents about $9 \%$ of the total energy use of arable crops (Audsley et al. 2009), the overall potential to avoid GHG emissions can be substantial.

The examples above show that crop protection and GHG emissions are strongly linked. However, it remains difficult to generalise whether the net GHG balance of crop protection is positive or negative (Kern et al. 2012), because the type of crop protection (e.g. chemical vs. biological) strongly influences both direct emissions for the treatment and the overall GHG emissions intensity per unit of food produced. However, based on current knowledge, it seems plausible that non-chemical pest control options can decrease GHG emissions intensity and not jeopardise adaptation efforts under CSPM.

\section{Increased productivity, improved farm livelihoods and strengthened food security}

The overarching goal of CSPM is the sustainable increase in productivity and incomes. This means bringing crop yields back to (or better than) pre-infestation levels and ensuring food production complies with national and international production standards (e.g. related to pesticide residues), so that smallholders are able to supply local and export markets in order to generate income. Several IPM-practices that can be considered under CSPM are outlined in this document and have been shown to increase crop yields. These include selecting pest-resistant crop varieties, intercropping, using cover crops, climate-adapted push-pull techniques, mulching, minimum tillage systems and other soil management practices.

However, interventions may also come with trade-offs (within CSPM but also between CSPM and other CSA practices), so it will be important to be able to predict and deal with any negative impacts the new practices put into place will have on crop yields. For example, drought-tolerant cassava planted to combat climate change has been found to be more susceptible to infestation by mealybugs, Phenacoccus herreni Cox and Williams (Pseudococcidae) in South America, and the mealybugs themselves are parasitised at lower rates, suggesting a decreased level of pest control and a consequent reduction in yield (Thomson et al. 2010). By anticipating negative effects such as these, a drop in yield following adaptation to climate change can be minimised or avoided.

\section{Challenges to adoption of climate-smart pest management}

Uptake of more sustainable, climate-smart practices related to pest management is slow (Bedmar Villanueva et al. 2016), with increased pesticide application being the principal strategy used by many farmers to handle climateinduced pest increases (Dhakal et al. 2016; Ziska 2014). The farm-level issues that hinder the immediate widespread adoption of more sustainable strategies are often emphasised, but institutional-level barriers at extension, research and policy levels also exist that, if addressed, would significantly enhance and accelerate adoption of more sustainable and climate-smart pest management 
approaches on multiple levels and indeed help to harmonise approaches on national and even regional scales.

\section{Crop production (farm and landscape)}

Barriers that impede adoption of CSPM practices include lack of sufficient knowledge about climate-smart practices, lack of resources, small farm sizes, lack of awareness and potentially high associated costs (Abid et al. 2016; Bedmar Villanueva et al. 2016; Macfadyen et al. 2018). Adaptation to climate change at farm level is also influenced by the willingness and ability to pay for available technologies, risks associated with trying a novel approach, cost of implementation, household demography, farm size, climate literacy of the farmer (particularly the head of household), household size and income, gender of the household head, access to markets, access to, and use of, climate information and extension services, availability of credit, and the prevailing climatic condition and its predictability (Belay et al. 2017; Below et al. 2012; Boansi et al. 2018; Deressa et al. 2011; FAO 2013a; Khatri-Chhetri et al. 2017; Tambo and Abdoulaye 2012, 2013). In terms of overcoming some of these barriers, the development of locally adapted CSPM approaches at farm and landscape levels using a participatory, bottom-up approach that engages the farming community, extension personnel and researchers can help to increase awareness and knowledge about climate change effects, enhance understanding of the social, financial and physical resources of the local farming community, as well as create ownership and motivation to implement adaptation/mitigation measures that have been developed jointly. Promoting the establishment of public or private financial mechanisms (e.g. access to microcredits) should also be a priority as this can bolster capacity of farmers and incentivise them to adopt novel approaches.

\section{Extension}

Being effective, responsive, accessible and well-informed are essential characteristics of an extension service that supports farmers with reorientation of pest management practices under climate change. However, extension systems in many countries lack these characteristics and this will therefore indirectly limit the potential of farmers to adapt. Some documented reasons for these shortcomings include lack of climate literacy amongst extension staff, chronic understaffing, limited operational funds, weak linkages to other stakeholders in the innovation process, including research, inconsistent dialogue between farmers and those who are tasked with supporting them, and the absence of reliable access to advisory services due to farmers' own restricted mobility (Bedmar Villanueva et al. 2016; CABI 2015; Heeb et al. 2016). Further reasons include a decline in appropriate expertise and financial support (Lamichhane et al. 2015), which together with a lack of quantitative evidence on how different pest management practices, as well how the broader farm- and landscape management systems, influence crop yields (food security), means that there may be no techniques to recommend with confidence (Harvey et al. 2014). Public and private sector investments are needed to develop a well-connected, well-informed and responsive extension system that will enhance adoption rates of CSPM strategies across farms and landscapes. Digital development will be instrumental in this reform and has the potential to increase efficiency, inclusiveness, outreach and impact. A good example of how a joint public-private collaboration is leading to a well-resourced and climate-responsive extension system is the case of the 'Colombian Coffee Grower's Federation' (FNC). In 1959, the FNC created its own extension system and has been continuously upgrading its operation. Nowadays, it employs about 1500 extension workers and serves over half a million affiliated farmers with services such as early warning systems based on climatic data analysis and modelling, issuing of monthly bulletins on expected climate variabilities, provision of crop management advice through a variety of complementary delivery channels (e.g. grower manuals, phone hotlines, radio), breeding and distribution of climate and pest resilient varieties, etc. In order to fund the number of subsidiary organisations responsible for the provision of these services, the FNC is financed by a public-private fund (the 'National Coffee Fund'). This fund is administrated by FNC and financed through a variable tax on coffee exports agreed by FNC and the Colombian Government (internal Plantwise assessment report 2016). With this funding model, costs for specific crop management practices are embedded in the producers' overall production costs; however, in return the smallholder coffee farmers receive an extremely high-quality extension service along with a number of other benefits, including price fluctuation control and purchase-guarantee. This demonstrates how a public-private partnership can implement a sustainable funding model that enables production costs to be absorbed while yielding benefits to all the value chain stakeholders.

\section{Research}

In an effective and functioning plant health system, the support provided by research institutes through the undertaking of need-based research is a necessary prerequisite to the development and implementation of novel and responsive CSPM strategies. However, barriers exist in many countries that prevent this vital service from functioning as it should. 
Examples of such barriers include reduced funding and decline in relevant specialist expertise (Lamichhane et al. 2015; Masters et al. 2010), inadequate education and training in crop protection to generate skilled crop protection specialists (Lamichhane et al. 2015), little research attention for specific sustainable management practices and poor regional research collaboration and coordination (Machekano et al. 2017). Investing money and resources in capacity enhancement and knowledge sharing at national and international research institutions, as well as ensuring that these institutions are well connected with extension, diagnostic facilities and climate information services will help ensure that research is need-based, collaborative and high quality, and that research findings are not confined within the boundaries of scientific literature but are made available to all stakeholders.

\section{Public sector}

Government policies and regulatory instruments need to provide clear direction and guidance to all other stakeholders to enable appropriate planning for climate change adaptation and effective targeting of resources and funds. However, challenges to making this a reality in many countries include the fact that existing policies are not informed by research evidence on local needs and constraints (Ampaire et al. 2017). In addition, there is a lack of funding and a shortage of relevant expertise in the field of crop protection (both in terms of the numbers of people and their technical background), both of which are required to develop appropriate adaptation plans or policies (Chakraborty and Newton 2011; Liu et al. 2016). Awareness raising and knowledge transfer at government level in the area of climate change impact and response approaches will help to enhance capacity for the development of well-informed and harmonised policies and regulatory instruments, addressing both adaptation and mitigation. Creating national designated funds that support the development of adaptation and mitigation plans would give substance to these policies. This in turn would stimulate financial sectors, businesses, civil society and international organisations to provide funding at multiple levels to put these plans into action.

The various challenges in implementing CSPM fall into different stakeholder categories but should not necessarily be considered and addressed in isolation. Many of the challenges are interlinked and interdependent, and interdisciplinary actions should be planned for optimal efficiency in addressing barriers and opening up maximum opportunities for adoption of CSPM approaches and technologies. With careful targeting of knowledge transfer, awareness raising, additional investment and policy development, the barriers can in most cases be addressed.

\section{Costs, benefits and funding for climate-smart pest management}

Costs of implementing CSPM depend on the interventions required at crop production (farm and landscape), extension, research and public/private levels, and must be considered in relation to short- and long-term monetary and non-monetary benefits. At the farm level, adoption of CSPM can influence input costs and crop yields. No cost-benefit analyses yet exists for CSPM, but analyses of IPM (which overlaps to a certain extent with CSPM at crop production level) show that IPM increases crop yields by up to $41 \%$, reduces pesticide use by an average of $31 \%$, and in most cases increases net returns (Norton and Mullen 1994; Pretty and Bharucha 2015). However, assessing financial benefits from IPM remains complicated, since many IPM projects involve interventions beyond pest management. CSPM and IPM also generate benefits by reducing negative external costs. These can be substantial if it is considered that costs of groundwater contamination by pesticides alone are as high as US\$2 billion/year in the USA (Pimentel 2005), or that 'worldwide, for every 100 agricultural workers, between one and three suffer acute pesticide poisoning, leading to many thousands of fatalities', and although developing countries use only $25 \%$ of the world's pesticides, they suffer $99 \%$ of the deaths due to pesticide poisoning (Chakraborty and Newton 2011). Furthermore, exposure to high quantities of agricultural pesticides during pregnancy can increase adverse birth outcomes by 5-9\% (Larsen et al. 2017). A cost-benefit analysis from an IPM-project in five villages of the Philippines demonstrated environmental benefits of US $\$ 150,000$, confirming the need to account for non-monetary benefits when assessing cost-efficiency of technologies that include plant protection (Cuyno et al. 2001).

On a national level, costs and benefits of CSPM could be significant. Establishing a national extension system able to fulfil the twofold role previously described requires important public/private sector investments in human capital and infrastructure. Unfortunately, investments in extension have decreased in recent decades despite evidence demonstrating that returns on investments can be substantial. For example, a multi-year randomised controlled trial (RCT) was implemented for Plantwise Kenya between 2014 and 2018; RCT is the most scientifically rigorous method of hypothesis testing and is considered as the gold standard for impact evaluation. The intervention of Plantwise Kenya specifically aimed to strengthen national plant health systems through building institutional capacity for issues like early detection and response and quality advice to manage pests. The RCT demonstrated that while the total costs of the Plantwise intervention were substantial (US\$669,000 in 2017 alone), the programme benefits (achieved through 
the impact on productivity and incomes) were even higher (US\$1,914,000). This gives a benefit-cost ratio of 2.9:1, and an internal rate of return (IRR) of 54\% (American Institute of Research 2018), thus proving that although the costs of increasing the responsiveness of extension systems are substantial, the benefits delivered far outweigh these costs. Another review estimates an average IRR of $80 \%$ for investments in extension (Dercon et al. 2009; GFRAS 2012). Similarly, the National Agricultural Advisory Services (NAADS) programme in Uganda estimates the IRR of programme expenditures to be between 8 and $49 \%$, with increases in gross revenue of farmers of between 37 and $95 \%$ (Benin et al. 2011).

Funding for CSPM requires joint efforts and coordination between public/private and domestic/international players because many pest problems need to be addressed using a cross-border approach. A few countries, including Rwanda, Sri Lanka, Bolivia, Cambodia and Myanmar, have recognised the need to include pest management in their national adaptation and mitigation priorities, as shown by analysis of their NDCs. Concrete funding proposals under existing frameworks and finance channels, such as National Appropriate Mitigation Actions and the Green Climate Fund, should now be explored to kick-start the implementation of CSPM. It is recognised that this will require the international community to provide substantial funding in the coming decades. The positive news is that the 'Katowice Climate Package' developed in the frame of COP24 (November 2018) includes a guideline that relates to 'the process for establishing new targets on finance from 2025 onwards to follow-on from the current target of mobilising USD 100 billion per year from 2020 to support developing countries' (UNFCCC 2018). This document therefore supports the setting of more ambitious financing targets for developed countries in support of climate action in developing countries. This can be considered as a major achievement from which the implementation of approaches like CSPM could potentially benefit.

An alternative way to fund the adoption of CSPM is through public policies encouraging uptake through regulatory instruments, such as incentive-based systems (e.g. taxes, subsidies or direct payments). Research findings can prove invaluable for the development of such systems as they can enable interventions to be better targeted towards the implementation of scientifically proven and locally relevant, sound management practices for more immediate and visible results (Larsen et al. 2019). A well-known and established policy with the aim of encouraging farmers to work in a sustainable and environmentally friendly manner is the EU's common agricultural policy (CAP), which is defined as a 'partnership between agriculture and society, and between Europe and its farmers' (European Commission 2018a). The CAP recognises that cost-efficiency pressure may influence farmers' behaviours towards highinput, unsustainable farming practices. Through income support actions, the CAP therefore incentivises farmers to undertake environmentally friendly farming through remunerating them for providing public goods (e.g. biodiversity, clean water and air) that are not directly paid for by the market. While critics state that the CAP is protectionist or harms developing countries, the policy comprises a number of effective instruments that promote the sustainable use of plant protection products (e.g. direct payments, 'green' direct payments, cross-compliance rules and agri-environmental measures) (European Commission 2018b) in line with the CSPM approach presented here. However, besides a number of positive outcomes as outlined in the Overview Report on Sustainable Use of Pesticides (European Commission 2017), one legitimate criticism of the CAP is that it has no mandatory instruments to encourage a transition towards low-input farming. As yet, the EU Directive on Sustainable Use of Pesticides has not been integrated into the CAP (PAN 2018). It is also worth noting that the CAP comes with a cost ( $€ 58.82$ billion in 2018 , of which $€ 41.74$ billion are for income support alone) (European Commission 2018a). However, it is important to relate these costs to the external costs caused by farming, which for pesticides (and their impact on human health and the environment) alone have been estimated for UK and Germany to be as high as US\$257 million and US\$166 million, respectively (Pretty and Waibel 2005).

As explained earlier, many developing countries are, however, experiencing a reduction in public funding for measures that would facilitate adoption of CSPM. This calls for alternative funding models, for example, through the private sector or through the recognition in the food markets (i.e. food standards). Integrating farm-based CSPM practices into existing product-based voluntary standards (e.g. Fairtrade, Rainforest Alliance) offers an opportunity for consumers to incentivise producers to adopt sustainable practices. Alternatively, supply chain certification standards (e.g. RSPO) could be particularly attractive for agricultural commodities and leverage additional private sector funding for uptake of CSPM. Also, retail companies have a significant influence on upstream value chain actors (including farmers) through the choice on type and quality of food products they wish to sell. This choice is not only demand and profit driven, but also includes a corporate social responsibility dimension that can lead to transactions favouring adoption of CSPM approaches.

Both systems (i.e. recognition in food markets and public policies) are well established for IPM in Europe but require consumers who are willing to pay a premium price and a public sector that is willing and able to compensate/penalise for positive or negative externalities (Lefebvre et al. 2015). 


\section{Interaction with other climate-smart agriculture practices}

CSPM is not a stand-alone approach due to its interface with existing farm-level and national-level CSA practices and approaches. Farmers who seek to adopt CSPM principles face multiple additional challenges and require holistic mitigation-compatible adaptation solutions. Integration and convergence between CSPM and existing CSA practices are multiple, because farm-level CSPM not only considers biotic factors, but also abiotic factors (e.g. crop nutrition) and crop husbandry (e.g. soil management). Certain CSA practices such as site-specific nutrient management, integrated soil fertility management, conservation agriculture, breeding for climate-resilient crops or crop diversification strategies are most relevant for the success of CSPM. Particular attention should be given to align CSPM with CSA approaches aiming at increasing gender responsiveness of the intervention, because while women produce more than half of the food grown worldwide, they produce $20-30 \%$ less yield than males due to reduced access to agricultural information and inputs among other factors (World Bank et al. 2009; FAO 2011). Therefore, gender-responsive planning is a critical component for the success of CSPM. An assessment of the likelihood of uptake of a climate-smart push-pull technology in East Africa (a low-cost approach to controlling maize stemborer such as Chilo spp. (Lepidoptera: Crambidae) and witchweed, Striga spp. (Orobanchaceae), while increasing soil fertility) shows that women were more willing to continue to use and upscale this technology, a fact that can be attributed to the technology characteristics that seemed to favour women's preferences (Murage et al. 2015).

\section{Conclusions}

FAO estimates that global food production will need to increase by $60 \%$ by mid-century in order to satisfy the needs of the growing world population and their changing diets (Alexandratos and Bruinsma 2012). However, climate change is already having impacts on agriculture, including through its effects on the biology, distribution and outbreak potential of pests across all land uses and landscapes. At the same time, agriculture is also a major climate change driver, since it remains the world's second largest emitter of GHG (IPCC 2014). Reducing the impact of pests is more important than ever to ensure global food security, reduced application of pesticides and decreased GHG emissions intensity per unit of food produced. This necessitates the immediate implementation of adaptation strategies at farm and landscape levels to decrease vulnerabilities of individual farmers and entire agricultural economies to the adverse effects of climate change, but also requires mitigation efforts to reduce global climate change, sustain food production and maintain livelihoods. In this context, the approach of CSPM seeks to support farmers, extension workers, scientists and public and private sector stakeholders to act in coordination and at scale to reorient pest management approaches and develop an appropriate enabling environment to manage evolving climate change-induced pest threats and invasions more effectively. It is anticipated that this approach can support policymakers in considering CSPM as a vehicle to achieve their commitments under the Paris Agreement as outlined in their NDCs.

\section{Author contributions}

LH and EJ conceived and designed the approach and wrote the manuscript. MC helped edit the manuscript thereafter. All authors read, revised and approved the manuscript.

Acknowledgements This review was developed from a 'climate-smart agriculture practice brief' prepared by CABI on behalf of the Global Alliance for Climate-Smart Agriculture (GACSA). CABI is an international intergovernmental organisation and we gratefully acknowledge the core financial support from our member countries (and lead agencies) including the UK (Department for International Development), China (Chinese Ministry of Agriculture), Australia (Australian Centre for International Agricultural Research), Canada (Agriculture and Agri-Food Canada), Netherlands (Directorate-General for International Cooperation) and Switzerland (Swiss Agency for Development and Cooperation). See https://www.cabi.org/about-cabi/who-we-work-with/ key-donors/ for details. The authors are also grateful to Dr Melanie Nicholls for her valuable contributions.

\section{Compliance with ethical standards}

Conflict of interest The authors declare that no conflict of interest exists.

Informed consent Informed consent was obtained from all individual participants included in the study.

Ethical approval This article does not contain any studies with human participants or animals performed by any of the authors.

Open Access This article is distributed under the terms of the Creative Commons Attribution 4.0 International License (http://creativeco mmons.org/licenses/by/4.0/), which permits unrestricted use, distribution, and reproduction in any medium, provided you give appropriate credit to the original author(s) and the source, provide a link to the Creative Commons license, and indicate if changes were made. 


\section{References}

Abid M, Schilling J, Scheffran J, Zulfiqar F (2016) Climate change vulnerability, adaptation and risk perceptions at farm level in Punjab, Pakistan. Sci Total Environ 547:447-460. https://doi. org/10.1016/j.scitotenv.2015.11.125

Agrhymet (2013) Centre Regional Agrhymet-Nos Produits. http:// www.agrhymet.ne/produit.html. Accessed 16 May 2018

Alexandratos N, Bruinsma J (2012) World agriculture towards 2030/2050: the 2012 revision, vol 12, no 3. ESA Working paper FAO, Rome. http://large.stanford.edu/courses/2014/ph240/yuan2 /docs/ap106e.pdf. Accessed 7 June 2018

Altieri MA (2012) Insect pest management in the agroecosystems of the future. Atti Accademia Nazionale Italiana di Entomologia, Anno LX 40:137-144. http://www.accademiaentomologia.it/ rendiconti/2012/03i\%20Altieri.pdf. Accessed 8 June 2018

Altieri MA, Nicholls CI (2003) Soil fertility management and insect pests: harmonizing soil and plant health in agroecosystems. Soil Tillage Res 72:203-211. https://doi.org/10.1016/S0167 -1987(03)00089-8

Altieri MA, Nicholls CI, Henao A, Lana MA (2015) Agroecology and the design of climate change-resilient farming systems. Agron Sustain Dev 35:869-890. https://doi.org/10.1007/s1359 3-015-0285-2

American Institute of Research (2018) Evaluation of plantwise-Kenya: 36-month follow-up report. https://www.plantwise.org/Uploads/ Plantwise/Air\%20Pw\%20K\%20Final\%20Report.pdf. Accessed 17 Dec 2018

Ampaire EL, Jassogne L, Providence H, Acosta M, Twyman J, Winowiecki L, van Asten P (2017) Institutional challenges to climate change adaptation: a case study on policy action gaps in Uganda. Environ Sci Policy 75:81-90. https://doi.org/10.1016/j. envsci.2017.05.013

Audsley E, Stacey KF, Parsons DJ, Williams AG (2009) Estimation of the greenhouse gas emissions from agricultural pesticide manufacture and use. Cranfield University. http://dspace.lib.cranfield. ac.uk/handle/1826/3913. Accessed 4 May 2018

Barzman M, Lamichhane JR, Booij K, Boonekamp P, Desneux N, Huber L, Kudsk P, Langrell SRH, Ratnadass A, Ricci P, Sarah J-L, Messean A (2015) Research and development priorities in the face of climate change and rapidly evolving pests. In: Lichtfouse E (ed) Sustainable agriculture reviews, vol 17. Springer, Cham, pp 1-27. https://doi.org/10.1007/978-3-31916742-8_1

Bebber DP, Ramotowski MA, Gurr SJ (2013) Crop pests and pathogens move polewards in a warming world. Nat Clim Change 3:985-988. https://doi.org/10.1038/nclimate1990

Beddington J, Asaduzzaman M, Clark M, Fernández A, Guillou M, Jahn M, Erda L, Mamo T, Van Bo N, Nobre CA, Scholes R, Sharma R, Wakhungu J (2012) Achieving food security in the face of climate change: final report from the Commission on Sustainable Agriculture and Climate Change. CGIAR Research Program on Climate Change, Agriculture and Food Security (CCAFS), Copenhagen, Denmark. https://cgspace.cgiar.org/ bitstream/handle/10568/35589/climate_food_commission-final -mar2012.pdf?sequence=1. Accessed $20 \mathrm{Feb} 2018$

Bedmar Villanueva A, Jha Y, Ogwal-Omara R, Welch E, Halewood M (2016) Adoption of climate smart technologies in East Africa: findings from two surveys and participatory exercises with farmers and local experts. CCAFS Info Note. CGIAR Research Program on Climate Change, Agriculture and Food Security, Copenhagen, Denmark. https://cgspace.cgiar.org/rest/bitstreams/67320 /retrieve. Accessed 20 Feb 2018

Belay A, Recha JW, Woldeamanuel T, Morton JF (2017) Smallholder farmers' adaptation to climate change and determinants of their adaptation decisions in the Central Rift Valley of Ethiopia. Agric Food Secur 6:24. https://doi.org/10.1186/s40066-017-0100-1

Below TB, Mutabazi KD, Kirschke D, Franke C, Sieber S, Siebert R, Tscherning K (2012) Can farmers' adaptation to climate change be explained by socio-economic household-level variables? Glob Environ Change 22:223-235. https://doi.org/10.1016/j.gloen vcha.2011.11.012

Benin S, Nkonya E, Okecho G, Randriamamonjy J, Kato E, Lubade G, Kyotalimye M (2011) Returns to spending on agricultural extension: the case of the National Agricultural Advisory Services (NAADS) program of Uganda. Agric Econ 42:249-267

Berry PM, Kindred DR, Paveley N (2008) Quantifying the effects of fungicides and disease resistance on greenhouse gas emissions associated with wheat production. Plant Pathol 57:1000-1008. https://doi.org/10.1111/j.1365-3059.2008.01899.x

Beuchelt TD, Badstue L (2013) Gender, nutrition-and climate-smart food production: opportunities and trade-offs. Food Secur 5:709721. https://doi.org/10.1007/s12571-013-0290-8

Boansi D, Tambo JA, Müller M (2018) Intra-seasonal risk of agriculturally-relevant weather extremes in West African Sudan Savanna. Theor Appl Climatol. https://doi.org/10.1007/s0070 4-018-2384-x

CABI (2015) Plantwise strategy 2015-2020. CABI, Wallingford,. https ://www.plantwise.org/Uploads/Plantwise/Plantwise\%20Strategy \%202015\%202020.pdf. Accessed 20 Feb 2018

Cagan L, Tancik J, Hassan S (1998) Natural parasitism of the European corn borer eggs Ostrinia nubilalis Hbn. (Lep., Pyralidae) by Trichogramma in Slovakia-need for field releases of the natural enemy. J Appl Entomol 122:315-318. https://doi. org/10.1111/j.1439-0418.1998.tb01504.x

CCAFS CGIAR (2017) A step forward for agriculture at the UN climate talks-Koronivia Joint Work on Agriculture. https:// ccafs.cgiar.org/blog/step-forward-agriculture-un-climate-talks -\%E2\%80\%93-koronivia-joint-work-agriculture\#.Ww0gbCBx12 Q. Accessed 15 May 2018

Chakraborty S, Newton AC (2011) Climate change, plant diseases and food security: an overview. Plant Pathol 60:2-14. https://doi.org /10.1111/j.1365-3059.2010.02411.x

Challinor AJ, Watson J, Lobell DB, Howden SM, Smith DR, Chhetri $\mathrm{N}$ (2014) A meta-analysis of crop yield under climate change and adaptation. Nat Clim Change 4:287-291. https://doi.org/10.1038/ nclimate 2153

Coakley SM, Scherm H, Chakraborty S (1999) Climate change and plant disease management. Annu Rev Phytopathol 37:399-426. https://doi.org/10.1146/annurev.phyto.37.1.399

Cock MJW (2011) Strategic entry points for funding taxonomic support to agriculture in developing countries. CABI Working Paper 3, 32 pp. https://www.cabi.org/Uploads/CABI/expertise/CABIWP3-TaxAg.pdf. Accessed 17 Dec 2018

Cock MJW, Biesmeijer JC, Cannon RJC, Gerard PJ, Gillespie D, Jiménez JJ, Lavelle PM, Raina SK (2013) The implications of climate change for positive contributions of invertebrates to world agriculture. CAB Rev Perspect Agric Vet Sci Nutr Nat Resour 8:28. https://doi.org/10.1079/pavsnnr20138028

Cock MJW, Tang R, Liu Z, Wan H, McGillivray LA, Thomas SE, Cameron KH, Zhang F (2016) The main agricultural pests and diseases of China and implications for the use of remote sensing for their management. CAB Rev 11:14. https://doi.org/10.1079/ pavsnnr201611014

Cock MJW, Beseh PK, Buddie AG, Cafá G, Crozier J (2017) Molecular methods to detect Spodoptera frugiperda in Ghana, and implications for monitoring the spread of invasive species in developing countries. Sci Rep 7:4103. https://doi.org/10.1038/ s41598-017-04238-y

Cuyno LCM, Norton GW, Rola A (2001) Economic analysis of environmental benefits of integrated pest management: a Philippine 
case study. Agric Econ 25:227-233. https://doi.org/10.1016/ S0169-5150(01)00080-9

de Sassi C, Tylianakis JM (2012) Climate change disproportionately increases herbivore over plant or parasitoid biomass. PLoS ONE 7:e40557

Dercon S, Gilligan DO, Hoddinott J, Woldehanna T (2009) The impact of agricultural extension and roads on poverty and consumption growth in fifteen Ethiopian villages. Am J Agric Econ 91:10071021. https://doi.org/10.1111/j.1467-8276.2009.01325.x

Deressa TT, Hassan RM, Ringler C (2011) Perception of and adaptation to climate change by farmers in the Nile basin of Ethiopia. $\mathrm{J}$ Agric Sci 149:23-31. https://doi.org/10.1017/s00218596100006 87

Dhakal S, Sedhain GK, Dhakal SC (2016) Climate change impact and adaptation practices in agriculture: a case study of Rautahat District, Nepal. Climate 4(63):1-22. https://doi.org/10.3390/cli40 40063

European Commission (2017) Overview report-sustainable use of pesticides. Publications Office of the European Union, Luxembourg. https://doi.org/10.2875/846869

European Commission (2018a) The common agricultural policy at a glance. https://ec.europa.eu/info/food-farming-fisheries/key-polic ies/common-agricultural-policy/cap-glance_en\#howitspaidfor. Accessed 17 Dec 2018

European Commission (2018b) Agriculture and pesticides. https:// ec.europa.eu/agriculture/envir/pesticides_en. Accessed 17 Dec 2018

FAO (2010) "Climate-Smart" agriculture: policies, practice and financing for food security, adaptation and mitigation. FAO, Rome, Italy. http://www.fao.org/docrep/013/i1881e/i1881e00.pdf. Accessed 20 Feb 2018

FAO (2011) The State of Food and Agriculture 2010-2011: women in agriculture: closing the gender gap for development. FAO, Rome, Italy. http://www.fao.org/docrep/013/i2050e/i2050e.pdf Accessed 20 Feb 2018

FAO (2013a) Climate-smart agriculture: sourcebook. FAO, Rome, Italy. http://www.fao.org/docrep/018/i3325e/i3325e.pdf Accessed 20 Feb 2018

FAO (2013b) International Standard for Phytosanitary Measure 5. FAO, Rome, Italy. https://www.ippc.int/en/publications/622/ Accessed 15 May 2018

Furlong MJ, Zalucki MP (2017) Climate change and biological control: the consequences of increasing temperatures on host-parasitoid interactions. Curr Opin Insect Sci 20:39-44. https://doi. org/10.1016/j.cois.2017.03.006

GFRAS (Global Forum for Rural Advisory Services) (2012) Factsheet on extension services. global forum for rural advisory services, Lindau, Switzerland. https://farmingfirst.org/wordpress/wp-conte nt/uploads/2012/06/Global-Forum-for-Rural-Advisory-Services_ Fact-Sheet-on-Extension-Services.pdf Accessed 20 Feb 2018

Gregory PJ, Johnson SN, Newton AC, Ingram JS (2009) Integrating pests and pathogens into the climate change/food security debate. J Exp Bot 60:2827-2838. https://academic.oup.com/jxb/artic le/60/10/2827/575879 Accessed 8 June 2018

Gu S, Han P, Ye Z, Perkins LE, Li J, Wang H, Zalucki MP, Lu Z (2018) Climate change favours a destructive agricultural pest in temperate regions: late spring cold matters. J Pest Sci 91:1191-1198. https://doi.org/10.1007/s10340-018-1011-z

Hance T, van Baaren J, Vernon P, Boivin G (2007) Impact of extreme temperatures on parasitoids in a climate change perspective. Annu Rev Entomol 52:107-126. https://doi.org/10.1146/annur ev.ento.52.110405.091333

Harvey CA, Chacón M, Donatti CI, Garen E, Hannah L, Andrade A, Bede L, Brown D, Calle A, Chará J, Clement C, Gray E, Hoang MH, Minang P, Rodríguez AM, Seeberg-Elverfeldt C, Semroc B, Shames S, Smukler S, Somarriba E, Torquebiau E, van Etten
J, Wollenberg E (2014) Climate-smart landscapes: opportunities and challenges for integrating adaptation and mitigation in tropical agriculture. Conserv Lett 7:77-90. https://doi.org/10.1111/ conl.12066

Hatfield JL, Boote KJ, Kimball BA, Ziska LH, Izaurralde RC, Ort DR, Thomson AM, Wolfe D (2011) Climate impacts on agriculture: implications for crop production. Agron J 103:351-370. https:// digitalcommons.unl.edu/usdaarsfacpub/1350 Accessed 20 Feb 2018

Heeb L, Jenner W, Romney D (2016) Promising innovative extension approaches for climate-smart agriculture: the plantwise example. In: Sala S, Rossi F, David S (eds) Supporting agricultural extension towards climate smart agriculture: an overview of existing tools. Global Alliance for Climate Smart Agriculture, pp 50-57. http://www.fao.org/3/a-bl361e.pdf. Accessed 21 May 2018

Heimpel GE, Yang Y, Hill JD, Ragsdale DW (2013) Environmental consequences of invasive species: greenhouse gas emissions of insecticide use and the role of biological control in reducing emissions. PLoS One 8:e72293. https://doi.org/10.1371/journ al.pone.0072293

Hellmann JJ, Byers JE, Bierwagen BG, Dukes JS (2008) Five potential consequences of climate change for invasive species. Conserv Biol 22:534-543. https://doi.org/10.111 1/j.1523-1739.2008.00951.x

Hoffmann AA, Weeks AR, Nash MA, Mangano GP, Umina PA (2008) The changing status of invertebrate pests and the future of pest management in the Australian grains industry. Aust J Exp Agric 48:1481-1493

Howden SM, Soussana J-F, Tubiello FN, Chhetri N, Dunlop M, Meinke $\mathrm{H}$ (2007) Adapting agriculture to climate change. Proc Acad Sci USA 104:19691-19696. https://doi.org/10.1073/pnas.07018 90104

Hughes DJ, West JS, Atkins SD, Gladders P, Jeger MJ, Fitt BDL (2011) Effects of disease control by fungicides on greenhouse gas emissions by UK arable crop production. Pest Manag Sci 67:1082-1092. https://doi.org/10.1002/ps.2151

Iltis C, Martel G, Thiéry D, Moreau J, Louâpre P (2018) When warmer means weaker: high temperatures reduce behavioural and immune defences of the larvae of a major grapevine pest. J Pest Sci 91:1315-1326. https://doi.org/10.1007/s10340-018-0992-y

IPCC (2014) Climate change 2014: synthesis report. Contribution of Working Groups I, II and III to the Fifth Assessment Report of the Intergovernmental Panel on Climate Change, p 151. IPCC 10013/epic.45156.d001

Jenner W, Cameron K, Reeder R (2019) Plantwise: monitoring plant pest outbreaks globally. In: Records AR, Ristaino JB (eds) Emerging plant diseases and global food security. American Phytopathological Society, St. Paul (in press)

Juroszek P, von Tiedemann A (2011) Potential strategies and future requirements for plant disease management under a changing climate. Plant Pathol 60:100-112. https://doi.org/10.111 1/j.1365-3059.2010.02410.x

Kern M, Noleppa S, Schwarz G (2012) Impacts of chemical crop protection applications on related $\mathrm{CO}_{2}$ emissions and $\mathrm{CO}_{2}$ assimilation of crops. Pest Manag Sci 68:1458-1466. https://doi. org/10.1002/ps.3328

Khatri-Chhetri A, Aggarwal PK, Joshi P, Vyas S (2017) Farmers' prioritization of climate-smart agriculture (CSA) technologies. Agric Syst 151:184-191. https://doi.org/10.1016/j.agsy.2016.10.005

Lamichhane JR, Barzman M, Booij K, Boonekamp P, Desneux N, Huber L, Kudsk P, Langrell SRH, Ratnadass A, Ricci P, Sarah J-L, Messéan A (2015) Robust cropping systems to tackle pests under climate change. A review. Agron Sustain Dev 35:443-459. https://doi.org/10.1007/s13593-014-0275-9

Lamichhane JR, Aubertot J-N, Begg G, Birch ANE, Boonekamp P, Dachbrodt-Saaydeh S, Hansen JG, Hovmøller MS, Jensen JE, 
Jørgensen LN, Kiss J, Kudsk P, Moonen A-C, Rasplusk J-V, Sattin M, Streitom J-C, Messéan A (2016) Networking of integrated pest management: a powerful approach to address common challenges in agriculture. Crop Prot 89:139-151. https://doi. org/10.1016/j.cropro.2016.07.011

Larsen AE, Gaines S, Deschênes O (2017) Agricultural pesticide use and adverse birth outcomes in the San Joaquin Valley of California. Nat Commun 8(1):302. https://doi.org/10.1038/s4146 7-017-00349-2

Larsen AE, Patton M, Martin EA (2019) High highs and low lows: elucidating striking seasonal variability in pesticide use and its environmental implications. Sci Total Environ 651:828-837. https://doi.org/10.1016/j.scitotenv.2018.09.206

Lefebvre M, Langrell SRH, Gomez-y-Paloma S (2015) Incentives and policies for integrated pest management in Europe: a review. Agron Sustain Dev 35:27-45. https://doi.org/10.1007/s1359 3-014-0237-2

Lin BB (2011) Resilience in agriculture through crop diversification: adaptive management for environmental change. BioSci 61:183193. https://doi.org/10.1525/bio.2011.61.3.4

Liu T, Ma Z, Huffman T, Ma L, Jiang H, Xie H (2016) Gaps in provincial decision-maker's perception and knowledge of climate change adaptation in China. Environ Sci Policy 58:41-51. https ://doi.org/10.1016/j.envsci.2016.01.002

Lobell DB, Field CB (2007) Global scale climate-crop yield relationships and the impacts of recent warming. Environ Res Lett 2:014002. https://doi.org/10.1088/1748-9326/2/1/014002

Macfadyen S, McDonald G, Hill MP (2018) From species distributions to climate change adaptation: knowledge gaps in managing invertebrate pests in broad-acre grain crops. Agric Ecosyst Environ 253:208-219. https://doi.org/10.1016/j.agee.2016.08.029

Machekano H, Mvumi BM, Nyamukondiwa C (2017) Diamondback moth, Plutella xylostella (L.) in Southern Africa: Research trends, challenges and insights on sustainable management options. Sustainability 9:91. https://doi.org/10.3390/su9020091

Masters G, Norgrove L (2010) Climate change and invasive alien species. CABI Work Pap 1:1-30

Masters G, Baker P, Flood J (2010) Climate change and agricultural commodities. CABI Work Pap 2:1-38

Mugambi I, Williams F, Muthomi J, Chege F, Oronje ML (2016) Diagnostic support to Plantwise plant doctors in Kenya. J Agric Ext Rural Dev 8(11):232-239. https://doi.org/10.5897/jaerd 2016.0808

Munkvold GP, Yang XB (1995) Crop damage and epidemics associated with 1993 floods in Iowa. Plant Dis 79:95-101. https://doi. org/10.1094/PD-79-0095

Murage AW, Pittchar JO, Midega CAO, Onyango CO, Khan ZR (2015) Gender specific perceptions and adoption of the climate-smart push-pull technology in eastern Africa. Crop Prot 76:83-91. https://doi.org/10.1016/j.cropro.2015.06.014

Musolin DL (2007) Insects in a warmer world: ecological, physiological and life-history responses of true bugs (Heteroptera) to climate change. Glob Change Biol 13:1565-1585. https://doi.org/ 10.1111/j.1365-2486.2007.01395.x

Musser FR, Shelton AM (2005) The influence of post-exposure temperature on the toxicity of insecticides to Ostrinia nubilalis (Lepidoptera: Crambidae). Pest Manag Sci 61:508-510. https:// doi.org/10.1002/ps.998

Mwongera C, Shikuku KM, Twyman J, Läderach P, Ampaire E, Van Asten P, Twomlow S, Winowiecki LA (2017) Climate smart agriculture rapid appraisal (CSA-RA): A tool for prioritizing context-specific climate smart agriculture technologies. Agric Syst 151:192-203. https://doi.org/10.1016/j.agsy.2016.05.009

Nandudu P (2014) As Uganda heats up, pests and disease flourish to attack its top export crop. http://www.globalissues.org/ news/2014/09/17/20036. Accessed 21 May 2018
Neufeldt H, Jahn M, Campbell BM, Beddington J.R., DeClerck F, De Pinto A, Gulledge J, Hellin J, Herrero M, Jarvis A, LeZaks D, Meinke H, Rosenstock T, Scholes M, Scholes R, Vermeulen S, Wollenberg E, Zougmoré R (2013) Beyond climate-smart agriculture: toward safe operating spaces for global food systems. Agric Food Secur 2:12. http://www.agricultureandfoodsecurit y.com/content $/ 2 / 1 / 12$. Accessed 8 June 2018

Norton GW, Mullen J (1994) Economic evaluation of integrated pest management programmes: a literature review. Virginia Cooperative Extension Publication 448-120. Virginia Polytechnic Institute and State University, Blacksburg, VA, USA. https:// vtechworks.lib.vt.edu/bitstream/handle/10919/24664/VCE44 8_120_1994.pdf?sequence $=1$. Accessed 20 Feb 2018

Oerke E-C (2006) Crop losses to pests. J Agric Sci 144:31-43. https:// doi.org/10.1017/S0021859605005708

Olesen JE, Bindi M (2002) Consequences of climate change for European agricultural productivity, land use and policy. Eur J Agron $16: 239-262$

PAN (2018) PAN Europe's position on 'the proposal for a new delivery model for the CAP after 2020'. Pesticide Action Network. https ://www.pan-europe.info/sites/pan-europe.info/files/PositionPa per_CAP_post2020.pdf. Accessed 17 Dec 2018

Pimentel D (2005) Environmental and economic costs of the application of pesticides primarily in the United States. Environ Dev Sustain 7:229-252. https://doi.org/10.1007/s10668-005-7314-2

Rosenstock TS, Lamanna C, Chesterman S, Bell P, Arslan A, Richards M, Rioux J, Akinleye AO, Champalle C, Cheng Z, CornerDolloff C, Dohn J, English W., Eyrich AS, Girvetz EH, Kerr A, Lizarazo M, Madalinska A, McFatridge S, Morris KS, Namoi N, Poultouchidou, N, da Silva MR, Rayess S, Ström H, Tully KL, Zhou, W (2016) The scientific basis of climate-smart agriculture: a systematic review protocol. Working Paper No. 138. CGIAR Research Program on Climate Change, Agriculture and Food Security (CCAFS), Copenhagen, Denmark. https://cgspace.cgiar .org/rest/bitstreams/66359/retrieve. Accessed 20 Feb 2018

Pretty J, Bharucha ZP (2015) Integrated pest management for sustainable intensification of agriculture in Asia and Africa. Insects 6:152-182. https://doi.org/10.3390/insects6010152

Pretty J, Waibel H (2005) Paying the price: the full cost of pesticides. The Pesticide Detox. Earthscan, London, pp 39-54

Rosenzweig C, Iglesias A, Yang XB, Epstein PR, Chivian E (2000) Implications of climate change for U.S. agriculture: Extreme weather events, plant diseases and pests. Center for Health and the Global Environment, Harvard Medical School, Cambridge, MA

Rosenzweig C, Iglesias A, Yang XB, Epstein PR, Chivian E (2001) Climate change and extreme weather events: implications for food production, plant diseases, and pests. Glob Change Hum Health 2:90-104. https://doi.org/10.1023/a:1015086831467

Scherm H (2004) Climate change: can we predict the impacts on plant pathology and pest management? Can J Plant Pathol 26:267-273. https://doi.org/10.1080/07060660409507143

Scherr SJ, Shames S, Friedman R (2012) From climate-smart agriculture to climate smart landscapes. Agric Food Secur 1(12):1-15. https://doi.org/10.1186/2048-7010-1-12

SciDevNet (2013) Deadly Striga weed spreading across Eastern Africa. http://www.scidev.net/sub-saharan-africa/food-security/ news/deadly-striga-weed-spreading-across-eastern-africa.html. Accessed 20 Feb 2018

Smith P, Martino D, Cai Z, Gwary D, Janzen H, Kumar P, McCarl B, Ogle S, O’Mara F, Rice C, Scholes B, Sirotenko O, Howden M, McAllister T, Pan G, Romanenkov V, Schneider U, Towprayoon S, Wattenbach M, Smith J (2008) Greenhouse gas mitigation in agriculture. Philos Trans R Soc Lond B Biol Sci 363(1492):789813. https://doi.org/10.1098/rstb.2007.2184 
Strand JF (2000) Some agrometeorological aspects of pest and disease management for the 21st century. Agric For Meteorol 103:73-82

Susko E, Spranger M, Tupas L, Brown J, Liffmann M (2013) The role of extension in climate adaptation in the United States. Report from the Land Grant-Sea Grant Climate Extension Summit. National Institute of Food and Agriculture and National Sea Grant College Program. https://nifa.usda.gov/sites/default/files /resources/climate_ext_summit.pdf. Accessed $20 \mathrm{Feb} 2018$

Sutherst RW, Constable F, Finlay KJ, Harrington R, Luck J, Zalucki MP (2011) Adapting to crop pest and pathogen risks under a changing climate. WIREs Clim Change 2:220-237. https://doi. org/10.1002/wcc. 102

Tambo JA, Abdoulaye T (2012) Climate change and agricultural technology adoption: the case of drought tolerant maize in rural Nigeria. Mitig Adapt Strat Glob Change 17:277-292. https:// doi.org/10.1007/s11027-011-9325-7

Tambo JA, Abdoulaye T (2013) Smallholder farmers' perceptions of and adaptations to climate change in the Nigerian savanna. Reg Environ Change 13:375-388. https://doi.org/10.1007/s1011 3-012-0351-0

Thomson LJ, Macfadyen S, Hoffmann AA (2010) Predicting the effects of climate change on natural enemies of agricultural pests. Biol Control 52:296-306. https://doi.org/10.1016/j.bioco ntrol.2009.01.022

Trumble JT, Butler CD (2009) Climate change will exacerbate California's insect pest problems. Calif Agric 63:73-78. https://doi. org/10.3733/ca.v063n02p73
Smith P, Bustamante M, Ahammad H, Clark H, Dong H, Elsiddig E.A., Haberl H, Harper R, House J, Jafari M, Masera O, Mbow C, Ravindranath NH, Rice CW, Robledo Abad C, Romanovskaya A, Sperling F, Tubiello, F (2014) Agriculture, forestry and other land use (AFOLU). In: Climate change 2014: mitigation of climate change. Contribution of Working Group III to the Fifth Assessment Report of the Intergovernmental Panel on Climate Change. Cambridge University Press, Cambridge, pp 811-922. http://www.ipcc.ch/pdf/assessment-report/ar5/wg3/ipcc_wg3_ ar5_chapter11.pdf. Accessed 21 May 2018

UNFCCC (2018) New era of global climate action to begin under paris climate change agreement. https://unfccc.int/news/new-era-ofglobal-climate-action-to-begin-under-paris-climate-change-agree ment-0. Accessed 17 Dec 2018

World Bank, FAO, IFAD (2009) Gender in agriculture sourcebook. The International Bank for Reconstruction and Development/The World Bank, Washington, DC, USA. http://siteresources.world bank.org/intgenagrlivsoubook/resources/completebook.pdf. Accessed 20 Feb 2018

Yonow T, Kriticos DJ, Kirichenko N, Ota N (2018) Considering biology when inferring range-limiting stress mechanisms for agricultural pests: a case study of the beet armyworm. J Pest Sci 91:523-528. https://doi.org/10.1007/s10340-017-0938-9

Ziska LH (2014) Increasing minimum daily temperatures are associated with enhanced pesticide use in cultivated soybean along a latitudinal gradient in the Mid-Western United States. PloS ONE 9:e98516. https://doi.org/10.1371/journal.pone.0098516 